\title{
Synthesis of a protected 2-ethoxy-3-hydroxyethylfuran and its regioselectivity as a Diels-Alder diene on reaction with 3,5- dimethoxydehydrobenzene
}

\author{
Robin G.F. Giles* and C. Peter Taylor \\ Chemistry Department, Murdoch University, Murdoch, WA 6150, Australia \\ E-mail: R.Giles@Murdoch.edu.au
}

\section{Dedicated to Dr. Douglas Lloyd on the occasion of his $80^{\text {th }}$ birthday}

\begin{abstract}
As a potential route for the synthesis of naturally occurring benzisochromanequinones, 2-ethoxy3-(1'-methoxymethoxyethyl)furan 15 was prepared and shown to react regioselectively with in situ generated 3,5-dimethoxydehydrobenzene to afford, after hydrolysis and alkylation, the target naphthalene 1-(6',8'-dimethoxy-1'-ethoxy-4'-isopropoxy-2'-naphthalenyl)-1(methoxymethoxy)ethane 27.
\end{abstract}

Keywords: Diels-Alder reaction, methoxyethylfurans, benzisochromanequinones

\section{Introduction}

In syntheses of naturally occurring benzisochromanequinones, ${ }^{1} \mathrm{C}-1$ and $\mathrm{O}-2$ of the ring system contained in structure $\mathbf{1}$ as well as the alkyl (usually methyl) substituent connected to C-1 are often derived from a hydroxyalkyl (usually hydroxyethyl) group attached to an appropriate naphthalenic precursor. ${ }^{2-4}$ Such hydroxyethylnaphthalenes are frequently obtained by the acetylation, followed by reduction, of a precursor naphthalene in additional sequential steps that reduce overall yields. Furthermore, the correct regioselectivity for the acetylation has to be achieved. A more convergent approach for the construction of the derived hydroxyethylnaphthalene might involve the use of a synthon already carrying this hydroxyethyl substituent. Having recently shown that oxygenated naphthalenes are readily synthesised with high regioselectivity and yields through addition of 3-methoxydehydrobenzenes to 2methoxyfuran, ${ }^{5}$ the extension of these studies to the use of a 3,5-dialkoxydehydrobenzene 2 with 
a protected 2-ethoxy-3-hydroxyethylfuran 3, as in Scheme 1, would afford the protected hydroxyethylnaphthol 4 in a one-pot reaction. In such a process, all the component atoms and bonds shown in bold in structure $\mathbf{1}$ would be incorporated using the single precursor synthon $\mathbf{3}$, and regioselectivity would also be achieved with respect to appropriate oxygenation on the aromatic rings. The naphthol $\mathbf{4}$ could then be elaborated further, for example via the corresponding hydroxyethylquinone using the recently reported Kobayashi enamine procedure. ${ }^{4}$ We now describe the synthesis of the methoxymethyl-protected 2-ethoxy-3-hydroxyethylfuran $\mathbf{1 5}$ and its regioselective addition to 3,5-dimethoxydehydrobenzene 20.

\section{Results and Discussion}

\section{The synthesis of the furan 13 and its derivatives}

Various methods were investigated for the synthesis of the unknown 2-ethoxy-3hydroxyethylfuran 13, including both modification of precursor furans as well as from noncyclic starting materials. Ultimately Yadav's application ${ }^{6}$ of Grigg's oxazole route ${ }^{7}$ to furans was employed, ${ }^{8}$ for which the starting material was (racemic) alanine. On a small scale this was converted directly into ethyl $\mathrm{N}$-formylalaninate $\mathbf{7}$ in good yield on heating with formic acid and ethanol in a glass ampoule, but it was not practical to scale up this method and the following procedure was therefore used. Alanine was initially converted into ethyl alaninate hydrochloride $\mathbf{5}$ (Scheme 2) using the literature procedure for the methyl ester. ${ }^{9}$ Although the hydrochloride $\mathbf{5}$ is reported to undergo direct $N$-formylation, ${ }^{10}$ improved yields were achieved by converting it into the free amino ester $\mathbf{6}$ using ethoxide. This intermediate $\mathbf{6}$ was reacted immediately with acetic formic anhydride to give ethyl $N$-formylalaninate 7 in a yield of 51\% from the hydrochloride 5 . The $N$-formyl ester 7 was cyclised through dehydration using phosphorus pentoxide in the presence of magnesium oxide $^{11}$ to afford the oxazole $\mathbf{8}$. While this oxazole was readily isolated, optimum yields were achieved when it was treated immediately, without isolation, with 3butyne-2-one 9 in a regioselective Diels-Alder reaction to afford the desired 3-acetyl-2ethoxyfuran $\mathbf{1 1}$ as the sole regioisomer. The addition of a small quantity of hydroquinone, to inhibit polymerisation, was found to increase the yield. This product $\mathbf{1 1}$ was obtained through the regioselective formation of the Diels-Alder adduct $\mathbf{1 0}$, and a subsequent retro-Diels-Alder reaction with the loss of acetonitrile, in a yield of $46 \%$ from the starting $N$-formylalaninate 7 . This regioselectivity, which was subsequently confirmed, was at this stage assumed from the anticipated polarisation of the alternative resonance contributors shown in Scheme 2. The related 3-acetyl-2-methoxyfuran 12 was obtained in a yield of 30\% from the corresponding methyl $\mathrm{N}$ formylalaninate. Since the overall yield for the ethoxy derivative was higher, this compound and 
its derivatives were used in subsequent experiments. In the ${ }^{1} \mathrm{H}$ NMR spectrum of each of these furans 11 and 12, the coupling constant between the two adjacent heterocyclic protons 4-H and 5- $\mathrm{H}$ was $2.3 \mathrm{~Hz}$, consistent with reported values for 2,3- (ortho-) coupling. ${ }^{12}$ Both furans were unstable and decomposed significantly within several hours at room temperature, although both could be stored for several months at temperatures below $-20{ }^{\circ} \mathrm{C}$.

Attempted reduction of furan $\mathbf{1 1}$ with lithium aluminium hydride led to its decomposition, while with sodium borohydride there was no reaction. The alcohol 13 was, however, obtained in excellent yield (92\%) by reduction of the ketone with sodium bis(2-methoxyethoxy)aluminium hydride (Red-Al) at room temperature in the presence of triethylamine. The structure of the alcohol was assigned on the basis of its ${ }^{1} \mathrm{H}$ and ${ }^{13} \mathrm{C}$ NMR and mass spectra. In the former, the acetyl methyl resonance of the starting material $\mathbf{1 1}$ at $\delta 2.34$ was replaced by resonances at $\delta$ $1.42, \delta 2.20$ and $\delta 4.80$ for the new methyl, hydroxy and methine protons in the product 13. In the ${ }^{13} \mathrm{C}$ NMR spectrum the carbonyl carbon signal at $\delta 191.6$ in the starting material was lost in the product. In the mass spectrum, fragmentation of the molecular ion of the product 13 at $\mathrm{m} / \mathrm{z}$ 156 afforded the base peak at m/z 139 and a second signal at m/z 138 (99\%), through loss of a hydroxyl radical and water respectively.

Several protecting groups for the alcohol were examined. Dissolution in pyridine followed by addition of acetic anhydride did not give the acetate, nor could the $t$-butyldimethylsilyl ether be formed with either the silyl chloride and imidazole or by using $t$-butyldimethylsilyl trifluoromethanesulphonate, decomposition of the alcohol 13 taking place instead. The benzyl ether 14 was formed in 63\% yield (as determined by ${ }^{1} \mathrm{H}$ NMR spectroscopy) using sodium hydride and benzyl bromide, although it was not possible to separate the product $\mathbf{1 4}$ completely from residual benzyl bromide. Protection of the alcohol $\mathbf{1 3}$ as the methoxymethyl derivative $\mathbf{1 5}$ was achieved in $70 \%$ yield with chloromethyl methyl ether and diisopropylethylamine in dichloromethane. In the mass spectrum of each of the ethers 14 and 15, the same fragment ion at $\mathrm{m} / \mathrm{z} 139$ was prominent, arising from loss of a benzyloxy or methoxymethoxy radical respectively.

\section{Diels-Alder reactions}

The reactivity of 3-acetyl-2-ethoxyfuran as a Diels-Alder diene was investigated. Attempted reaction of the furan $\mathbf{1 1}$ with the common dienophile maleic anhydride under various conditions of solvent and temperature (including in a sealed ampoule at $150{ }^{\circ} \mathrm{C}$ in toluene) afforded no products of cycloaddition. On prolonged treatment with the strongly dienophilic dimethyl acetylene dicarboxylate in benzene under reflux, however, the known ${ }^{7}$ furan $\mathbf{1 6}$ was obtained in moderate yield. This product had been obtained previously by Grigg on reaction of the oxazole $\mathbf{8}$ with this latter dienophile. 
It was recognized at the outset that production of a benzyne (Scheme 1) in situ under basic conditions in the presence of the acetylfuran $\mathbf{1 1}$ could lead instead to removal of an acetyl proton. Use of 2-bromo-3,5-dimethoxyphenyl $p$-toluenesulfonate $\mathbf{1 9}^{5}$ as the precursor to 3,5dimethoxybenzyne 20 and butyl lithium (one equivalent) as the base might, however, lead to preferential lithium - halogen exchange, and therefore generation of the benzyne $\mathbf{2 0}$ in the presence of the acetylfuran. The successful regioselective reaction of these would lead to the formation of acetylnaphthols and thence acetylnapthoquinones related to those used by the Brimble route $^{13}$ to benzisochromanequinones. In practice, however, only products of decomposition were observed. The in situ generation of benzyne itself under neutral conditions (from anthranilic acid and isoamyl nitrite ${ }^{14}$ ) in the presence of the acetylfuran $\mathbf{1 1}$ also gave the same result. This suggested that the acetylfuran $\mathbf{1 1}$ was a poor diene in comparison with 2methoxyfuran. ${ }^{5}$

No reaction took place between the hydroxyethylfuran 13 and either maleic anhydride or the butynone 9. This diene did react readily, however, with dimethyl acetylene dicarboxylate to afford the unstable adduct $\mathbf{1 7}$ in 72\% yield, which was identified by ${ }^{1} \mathrm{H}$ NMR spectroscopy. This rearranged under the influence of hydrochloric acid to give the phenol $\mathbf{1 8}$ in high yield. The diene 13 was not necessarily expected to undergo a Diels-Alder reaction with the benzyne 20, since alcohols are known to react as nucleophiles with methoxybenzynes, ${ }^{15}$ and, in practice, no product was isolated.

The reactions of the protected furan alcohols with 3,5-dimethoxybenzyne $\mathbf{2 0}$ produced in situ were examined. When the benzyl protected derivative 14 was reacted with the bromotosylate 19 in the presence of butyl lithium, the presumed Diels-Alder adduct 21 was treated with trifluoroacetic acid, and the derived mixture was reacted with acetic anhydride and pyridine, the naphthyl acetate $\mathbf{2 4}$ was isolated in 24\% yield (Scheme 3). In addition, a small amount (8\%) of the naphthol $\mathbf{2 3}$ was obtained. The formation of this additional naphthol may have arisen through acidic work-up of the acetate $\mathbf{2 4}$ to remove pyridine used in its formation, either through hydrolysis of the acetate or from residual adduct $\mathbf{2 1}$ remaining from its incomplete ring-opening prior to acetylation of the naphthol 23.

When the same benzyne $\mathbf{2 0}$ was produced in situ in the presence of the methoxymethyl protected alcohol 15, the adduct ring-opened and the derived naphthol 25 acetylated (Scheme 3), the naphthyl acetate 26 was obtained in $41 \%$ overall yield based on furan 15. This represented an average yield for each of the three steps of approximately 75\%. Alternatively, when the naphthol 25 was protected as the 2-propyl ether 27, this was isolated in $23 \%$ yield, with a further $10 \%$ of the precursor naphthol 25 also being recovered. 
Proof was sought for the anticipated regiochemistry of the naphthalene $\mathbf{2 7}$ arising from the cycloaddition reaction between the protected hydroxyethylfuran $\mathbf{1 5}$ and the benzyne $\mathbf{2 0}$. Initially, the conversion of $\mathbf{2 7}$ into a known compound was examined. As a preliminary step, the removal of the methoxymethyl protecting group was attempted, first with concentrated hydrochloric acid and, subsequently, with trifluoroacetic acid. This led in both cases only to products of decomposition. Milder conditions were then sought. With trimethylsilyl bromide ${ }^{16}$ in methylene dichloride the vinylnaphthalene $\mathbf{2 8}$ was isolated as the sole product in a yield of $14 \%$. The same product 28 was also isolated in 55\% yield using pyridinium $p$-toluenesulfonate in 2-butanone. ${ }^{17}$ This presumably arises through attachment of the electrophile (X $=\mathrm{H}$ or TMS, Scheme 4$)$ to a methoxymethyl oxygen (as in 29) followed by expulsion of the side-chain, this being promoted by the ethoxy and two aromatic methoxy substituents.

Support for the assigned regiochemistry in compound $\mathbf{2 7}$ was obtained from a two-dimensional NOESY spectrum. The proximities between the relevant protons are shown in red in Figure 1. In particular, the ethoxy group was in close proximity to the 8-methoxy substituent, the methylene protons of the methoxymethyl group and the benzylic methine proton of the alkoxyethyl sidechain. The isopropoxy substituent was found to be adjacent to the aromatic protons H-3 and H-5. From these results it can be seen that the furan 11, and therefore furan 12, are the 2,3disubstituted structural isomers assumed above and also that cycloaddition of the furan $\mathbf{1 5}$ (and therefore furan 14) and the benzyne 20 occurred with the anticipated regiochemistry for the only naphthalene isolated.

\section{Conclusions}

Syntheses for the 3-acetyl-2-alkoxyfurans $\mathbf{1 1}$ and $\mathbf{1 2}$ were readily developed, together with those of the related 3-hydroxyethylfuran 13 and its protected derivative 15. Conditions have yet to be established for the use of the latter as an appropriate synthon for the synthesis of benzisochromanequinones. The acetylfurans were poor Diels-Alder dienes, reacting slowly and in moderate yield with the strongly dienophilic dimethyl acetylene dicarboxylate, but not with either maleic anhydride or benzyne. The hydroxyethylfuran 13 reacted rapidly and in very good yield with the first of these dienophiles. Its methoxymethyl derivative 15 reacted with the dienophile 3,5-dimethoxybenzyne $\mathbf{2 0}$ with the desired regioselectivity, although the yields of the derived naphthalenes were somewhat lower than for the analogue 2-methoxyfuran. ${ }^{5}$ Presumably this arose on account of the greater sensitivity of the substituents in the present study to the acid treatment required to convert the Diels-Alder adduct into naphthalenes. 

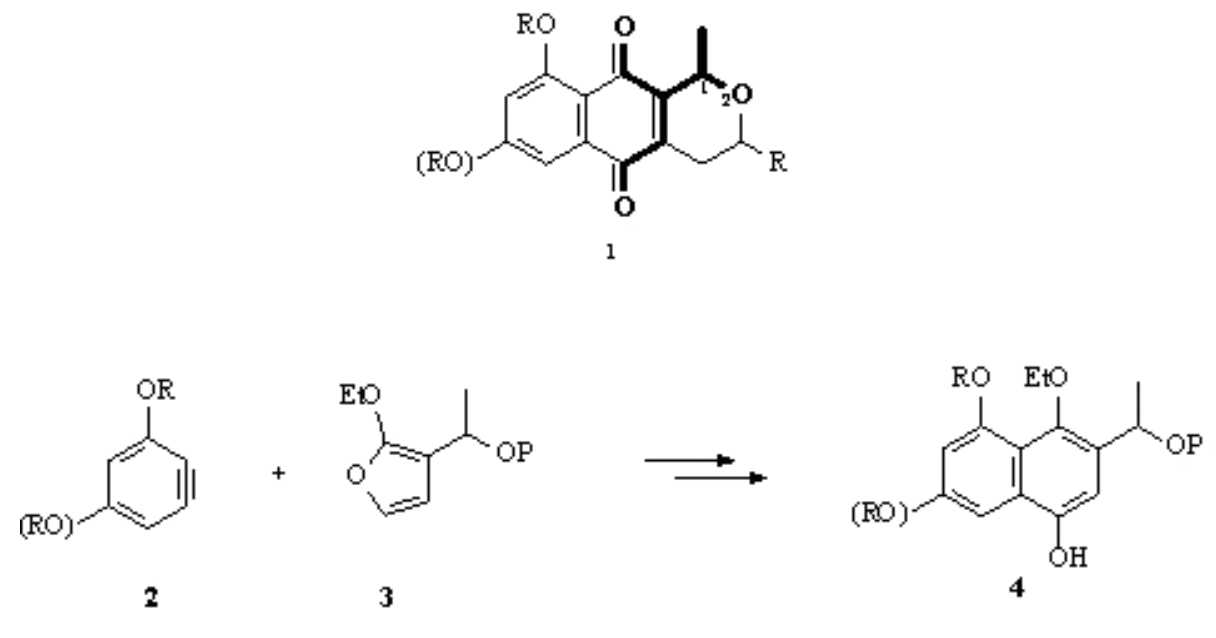

\section{Scheme 1}

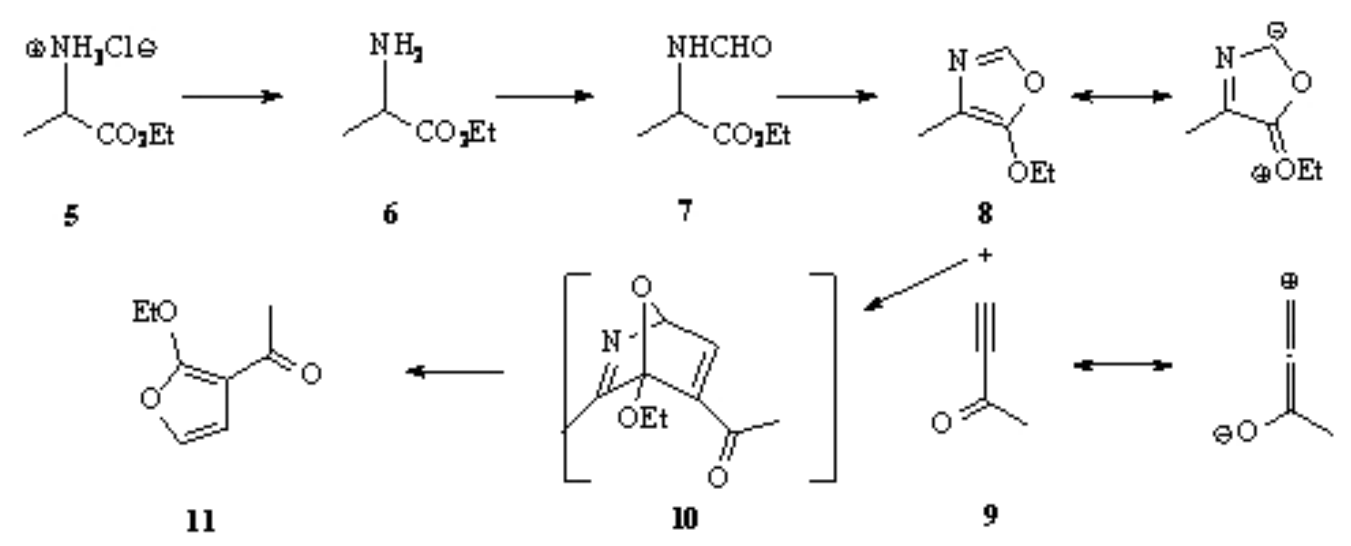

Scheme 2 
<smiles>COc1occc1C(C)=O</smiles>

12

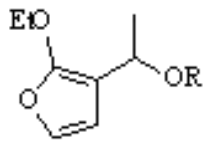

$13 \mathrm{R}=\mathrm{H}$

$14 \mathrm{R}=\mathrm{CH}_{3} \mathrm{Ph}$

15 $\mathrm{R}=\mathrm{CH}_{3} \mathrm{OMe}$

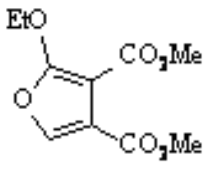

16

\section{Scheme 3}

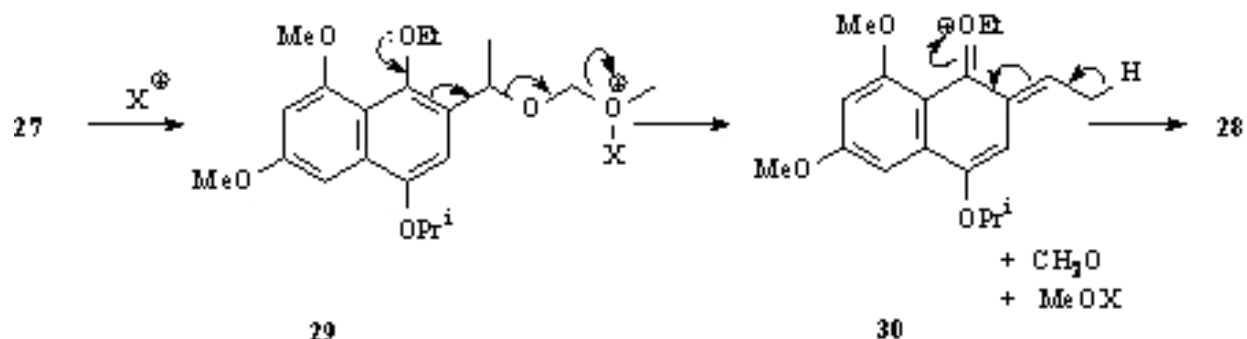

\section{Scheme 4}

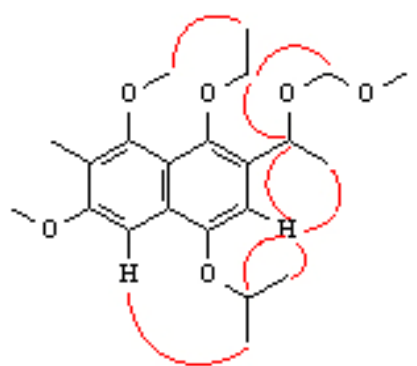

Figure 1 


\section{Experimental Section}

General Procedures. Nuclear magnetic resonance spectra were recorded using either a Hitachi R24B spectrometer ( ${ }^{1} \mathrm{H} 60 \mathrm{MHz}$ ), a Bruker AM-300 or a Bruker Avance DPX-300 spectrometer $\left({ }^{1} \mathrm{H} 300 \mathrm{MHz},{ }^{13} \mathrm{C} 75.5 \mathrm{MHz}\right)$. All spectra were run on the latter two instruments unless otherwise stated. These spectra were recorded at ambient temperature in deuterochloroform $\left(\mathrm{CDCl}_{3}\right)$ using tetramethylsilane (TMS) as an internal standard. In the ${ }^{13} \mathrm{C} \mathrm{NMR}$ spectra, assignments of signals with the same superscript are interchangeable. Mass spectra were recorded on either a Hewlett Packard 5986 spectrometer at $35 \mathrm{eV}$, or on a Perkin-Elmer ITD Ion Trap Detector spectrometer at $55 \mu \mathrm{A}$ with automatic gain control. High resolution mass spectra were recorded on a VG Autospec High Resolution Mass Spectrometer. Infrared spectra were recorded as thin films between $\mathrm{KBr}$ plates for oils and as $\mathrm{KBr}$ discs for solids using a PerkinElmer 1720-X Fourier Transform Spectrometer. Melting points are uncorrected and were recorded on a Reichert hot stage apparatus. Column chromatography was carried out on columns prepared as slurries of Merck silica gel 60 (70-230 mesh) in the eluent. Preadsorption was carried out on Merck silica gel 60 (35-70 mesh). Radial chromatography was performed using Merck silica gel $60 \mathrm{PF}_{254}$. Preparative layer chromatography was performed on glass plates coated with Carmag silica gel as a $0.3 \mathrm{~mm}$ thick layer, while thin layer chromatography was carried out on aluminium plates coated with Merck Kieselgel $60 \mathrm{~F}_{254}$. Petroleum ether refers to the fraction of boiling point $65-70{ }^{\circ} \mathrm{C}$. All solvents were purified by distillation and, if necessary, were dried according to standard methods. The amount of residual water present in solvents was determined using a Metrohm Karl Fischer Coulometer 684.

Ethyl $N$-formyl alaninate (7). (a) A solution of DL-alanine (1.00 g, $11.2 \mathrm{mmol})$ and formic acid (2.58 g, $56.1 \mathrm{mmol})$ in ethanol $\left(13 \mathrm{~mL}\right.$ ) was heated in a sealed glass ampoule at $150{ }^{\circ} \mathrm{C}$ overnight (16 h). The mixture was then cooled and distilled on a Kugelrohr at $130{ }^{\circ} \mathrm{C} / 0.12 \mathrm{mmHg}$ to give the known title compound 7 (1.20 g, 74\%) (lit., $\left.{ }^{10} 100{ }^{\circ} \mathrm{C} / 0.1 \mathrm{mmHg}\right) ; \delta_{\mathrm{H}}(60 \mathrm{MHz}) 1.28$ (3H, t, $J$ 7.2, $\mathrm{CH}_{2} \underline{\mathrm{C}}_{3}$ ), 1.43 (3H, d, J 7.2, $\mathrm{CHCH}_{3}$ ), 4.21 (2H, q, J 7.2, $\left.\mathrm{C}_{2} \mathrm{CH}_{3}\right), 4.44-4.90$ (1H, m, $\mathrm{C}_{\mathrm{HCH}}$ ), 7.20 (1H, br. s, NH), 8.18 (1H, s, CHO). (b) Sodium metal (1.62 g, 70.5 mmol) was added to dry ethanol $(50 \mathrm{~mL})$ and the reaction stirred until all the metal had been dissolved. The solvent was then removed under reduced pressure and the residue dissolved in dry tetrahydrofuran (50 mL). Alaninate hydrochloride 5 (9.86 g, $64.2 \mathrm{mmol}$ ) was added and the mixture stirred for $2 \mathrm{~h}$ to give a solution of ethyl alaninate $\mathbf{6}$ in tetrahydrofuran. Acetic anhydride (26.21 g, $256.7 \mathrm{mmol}$ ) was added to a solution of sodium formate (17.46 g, $256.7 \mathrm{mmol}$ ) in dry tetrahydrofuran $(40 \mathrm{~mL})$. The reaction was cooled to $0{ }^{\circ} \mathrm{C}$ and formic acid $(11.82 \mathrm{~g}, 256.8 \mathrm{mmol})$ added dropwise. The reaction was then warmed to $35-40{ }^{\circ} \mathrm{C}$ for $1 \mathrm{~h}$ and then cooled to room 
temperature for $10 \mathrm{~min}$. The mixture was cooled to $0{ }^{\circ} \mathrm{C}$ and the solution of ethyl alaninate 6 in tetrahydrofuran was added dropwise. The reaction was stirred at $0{ }^{\circ} \mathrm{C}$ for $1 \mathrm{~h} 30 \mathrm{~min}$ and then at room temperature overnight $(18 \mathrm{~h})$. The reaction was concentrated, the residue dissolved in ethyl acetate $(100 \mathrm{~mL})$ and then washed with saturated aqueous sodium hydrogen carbonate. The combined organic layers were dried (magnesium sulfate) and concentrated. The residue was distilled on a Kugelrohr at $150{ }^{\circ} \mathrm{C} / 0.8 \mathrm{mmHg}$ to give the known ${ }^{10}$ title compound 7 (4.18 g, $51 \%)$.

3-Acetyl-2-ethoxyfuran (11). A solution of ethyl $N$-formylalaninate 7 (2.74 g, $18.9 \mathrm{mmol}$ ) in dry chloroform (50 mL) was added to a stirred mixture of phosphorus pentoxide (16.06 g, 113.1 mmol), magnesium oxide (4.64 g, $115.1 \mathrm{mmol}$ ) and filter aid (4.60 g) in dry chloroform (140 $\mathrm{mL}$ ) under nitrogen. The reaction was stirred at room temperature for $30 \mathrm{~min}$ and then heated under reflux overnight (19 h). The mixture was cooled and saturated aqueous sodium hydrogen carbonate $(300 \mathrm{~mL})$ was added carefully. The solution was filtered and the resulting layers separated. The aqueous layer was extracted with dichloromethane. The combined organic layers were washed with water and dried (magnesium sulfate). Careful removal of the solvent under vacuum gave the oxazole 8 as a pale yellow oil $\left[\delta_{\mathrm{H}}(60 \mathrm{MHz}) 1.32\left(3 \mathrm{H}, \mathrm{t}, J\right.\right.$ 7.2, $\left.\mathrm{CH}_{2} \mathrm{CH}_{3}\right), 2.00$ $\left.\left(3 \mathrm{H}, \mathrm{s}, 4-\mathrm{CH}_{3}\right), 4.05\left(2 \mathrm{H}, \mathrm{q}, J \mathrm{7.2}, \mathrm{CH}_{2} \mathrm{CH}_{3}\right), 7.25(1 \mathrm{H}, \mathrm{s}, 2-\mathrm{H})\right]$ which was immediately dissolved in dry toluene $(40 \mathrm{~mL})$. To this solution was added hydroquinone (40 mg) and 3-butyn2-one 9 (1.54 g, $22.6 \mathrm{mmol}$ ), and the mixture, under nitrogen, stirred under reflux for $5 \mathrm{~h} 30 \mathrm{~min}$. Cooling, followed by concentration, gave a yellow oil which was immediately purified by column chromatography (10-20\% ethyl acetate-petroleum ether) to give the product $\mathbf{1 1}$ as pale yellow crystals (1.34 g, 46\%) mp $45-46.5{ }^{\circ} \mathrm{C}$ (from hexane) (Found: $\mathrm{C}, 62.0 ; \mathrm{H}, 6.55 . \mathrm{C}_{8} \mathrm{H}_{10} \mathrm{O}_{3}$ requires C, 62.35; H, 6.55\%); $v_{\max } / \mathrm{cm}^{-1} 2988(\mathrm{C}-\mathrm{H}), 1644(\mathrm{C}=\mathrm{C}), 1581(\mathrm{C}=\mathrm{O}), 1450(\mathrm{C}=\mathrm{C})$, 1124 (C-O); $\delta_{\mathrm{H}} 1.42$ (3H, t, J 7.1, $\left.\mathrm{CH}_{2} \underline{\mathrm{CH}}_{3}\right), 2.34$ (3H, s, $\left.\mathrm{COCH}_{3}\right), 4.42\left(2 \mathrm{H}, \mathrm{q}, J\right.$ 7.1, $\left.\mathrm{CH}_{2}\right), 6.62$ (1H, d, J 2.3, 4-H), $6.79\left(1 \mathrm{H}, \mathrm{d}, J\right.$ 2.3, 5-H); $\delta_{\mathrm{C}} 14.9\left(\mathrm{CH}_{2} \underline{\left.\mathrm{CH}_{3}\right),} 28.4\left(\mathrm{COC}_{3}\right), 67.3\left(\mathrm{CH}_{2}\right)\right.$, 101.9 (C-3), 110.5 (C-4), 132.8 (C-5), 162.1 (C-2), 191.6 (CO); m/z 155 (M+1, 94\%), 126 (100), 111 (42), 84 (45), 69 (51), 53 (45).

3-Acetyl-2-methoxyfuran (12). Using the method described above, the product 12 was obtained as white needles (0.145 g, 30\%) mp 41.5-42 ${ }^{\circ} \mathrm{C}$ (from hexane) (Found: $\mathrm{M}^{+}, 140.0471 . \mathrm{C}_{7} \mathrm{H}_{8} \mathrm{O}_{3}$ requires $\mathrm{M}, 140.0473)$; $v_{\max }\left(\mathrm{KBr}\right.$ disc) $1648(\mathrm{C}=\mathrm{O}), 1596(\mathrm{C}=\mathrm{C}), 1475(\mathrm{C}=\mathrm{C}), 1423(\mathrm{C}=\mathrm{C}) ; \delta_{\mathrm{H}}$ $2.34\left(3 \mathrm{H}, \mathrm{s}, \mathrm{COCH}_{3}\right), 4.09\left(3 \mathrm{H}, \mathrm{s}, \mathrm{OCH}_{3}\right), 6.63(1 \mathrm{H}, \mathrm{d}, J 2.3,4-\mathrm{H}), 6.82(1 \mathrm{H}, \mathrm{d}, J 2.3,5-\mathrm{H}) ; \delta_{\mathrm{C}}$ $28.4\left(\mathrm{COCH}_{3}\right), 57.6\left(\mathrm{OCH}_{3}\right), 101.3$ (C-3), 110.8 (C-4), 132.8 (C-5), 162.4 (C-2), 191.8 (CO); m/z $140\left(\mathrm{M}^{+}, 58 \%\right), 125$ (100), 110 (32), 83 (22), 82 (15), 69 (16). 
2-Ethoxy-3-(1'-hydroxyethyl)furan (13). To a stirred solution of 3-acetyl-2-ethoxyfuran 11 $(0.305 \mathrm{~g}, 1.98 \mathrm{mmol})$ and dry triethylamine $(1 \mathrm{~mL})$ in dry toluene $(4 \mathrm{~mL})$ under nitrogen was added sodium bis(2-methoxyethoxy)aluminium hydride $(0.200 \mathrm{~g}, 0.99 \mathrm{mmol})$. The mixture was stirred for $30 \mathrm{~min}$, after which saturated aqueous sodium hydrogen carbonate $(10 \mathrm{~mL})$ was added and stirring continued for $30 \mathrm{~min}$. The reaction mixture was extracted with diethyl ether and the organic layers dried (magnesium sulfate). Concentration of the crude solution gave virtually pure product 13 as an unstable pale yellow oil (0.284 g, 92\%) (Found: $\mathrm{M}^{+}-1,155.0703 . \mathrm{C}_{8} \mathrm{H}_{11} \mathrm{O}_{3}$ requires M-1, 155.0708); $v_{\max }$ 3396(O-H), 2977 (C-H), 1641 (C=C), 1059 (C-O), 1032 (C-O); $\delta_{\mathrm{H}} 1.35\left(3 \mathrm{H}, \mathrm{t}, J\right.$ 7.1, $\left.\mathrm{CH}_{2} \mathrm{CH}_{3}\right), 1.42$ (3H, d, $J$ 6.5, 2'- $\left.\mathrm{CH}_{3}\right), 2.20$ (1H, br. s, OH), 4.19 (2H, q, $J$ 7.1, $\left.\mathrm{CH}_{2}\right), 4.80\left(1 \mathrm{H}, \mathrm{q}, J\right.$ 6.5, 1'-H), $6.32\left(1 \mathrm{H}, \mathrm{d}, J\right.$ 1.9, 4-H), $6.86(1 \mathrm{H}, \mathrm{d}, J 1.9,5-\mathrm{H}) ; \delta_{\mathrm{C}} 15.1$ $\left(\mathrm{CH}_{2} \mathrm{CH}_{3}\right), 23.4\left(\mathrm{C}-2^{\prime}\right), 61.5\left(\mathrm{C}-1^{\prime}\right), 68.7\left(\mathrm{CH}_{2}\right), 104.2$ (C-3), 109.6 (C-4), 133.2 (C-5), $155.0(\mathrm{C}-$ 2); m/z 157 (M+1, 34\%), $156\left(\mathrm{M}^{+}, 36\right), 139$ (100), 138 (99), 111 (50), 110 (46), 81 (65), 53 (52).

2-Ethoxy-3-(1'-benzyloxyethyl)furan (14). A solution of furan 13 (0.145 g, $0.93 \mathrm{mmol})$ in dry dimethylformamide: dry tetrahydrofuran $(2 \mathrm{~mL}, 1: 4)$ was added dropwise to a suspension of sodium hydride (24 mg, $1.00 \mathrm{mmol})$ in dry dimethylformamide: dry tetrahydrofuran (2 mL, 1:4) at $0{ }^{\circ} \mathrm{C}$. The mixture was stirred at $0{ }^{\circ} \mathrm{C}$ for $5 \mathrm{~min}$ and benzyl bromide $(0.476 \mathrm{~g}, 2.78 \mathrm{mmol})$ was then added. The reaction was stirred for a further $25 \mathrm{~min}$ at $0{ }^{\circ} \mathrm{C}$ and then at room temperature overnight (19 h). The reaction was quenched with saturated aqueous sodium hydrogen carbonate and extracted with diethyl ether. The organic extracts were dried (magnesium sulfate) and chromatographed (5-10\% ethyl acetate-petroleum ether-1\% triethylamine) to give an inseparable mixture of benzyl bromide and product 14 (0.144 g product, $0.307 \mathrm{~g}$ benzyl bromide, 1:2.1 w/w, 63\% yield by ${ }^{1} \mathrm{H}$ NMR); $v_{\max } / \mathrm{cm}^{-1} 3031$ (C-H), 2978 (C-H), 1640 (C=C), 1454 $(\mathrm{C}=\mathrm{C}) ; \delta_{\mathrm{H}}$ (mixture of product 14 and benzyl bromide) 1.27 (3H, t, $J$ 7.1, $\mathrm{CH}_{2} \underline{\mathrm{C}}_{3}$ ), 1.42 (3H, d, $J$ 6.5, 1'- $\mathrm{CH}_{3}$ ), 4.12 (2H, q, J 7.1, $\mathrm{C}_{2} \mathrm{CH}_{3}$ ), 4.39 (2H, s, $\underline{\mathrm{C}}_{2} \mathrm{Ph}$ and benzyl bromide), 4.44-4.51 $(1 \mathrm{H}, \mathrm{m}, 1 '-\mathrm{H}), 6.32(1 \mathrm{H}, \mathrm{d}, J$ 2.2, 4-H), $6.86(1 \mathrm{H}, \mathrm{d}, J$ 2.2, 5-H), 7.21-7.32 (5H, m, Ph-H and benzyl bromide); $\delta_{\mathrm{C}}$ (mixture of product 14 and benzyl bromide) $14.9\left(\mathrm{CH}_{2} \underline{\left.\mathrm{CH}_{3}\right),} 21.8\left(\mathrm{C}-2^{\prime}\right)\right.$, 33.4 (benzyl bromide), 67.3 (C-1'), $68.3\left(\underline{\mathrm{CH}}_{2} \mathrm{CH}_{3}\right),{ }^{\mathrm{a}} 69.4\left(\underline{\mathrm{CH}}_{2} \mathrm{Ph}\right),{ }^{\mathrm{a}} 101.2$ (C-3), 109.7 (C-4), 127.1 (C-4"), 127.6 (C-2" and C-6"), 128.0 (C-3" and C-5"), 128.2 (benzyl bromide), 128.5 (benzyl bromide), 128.8 (benzyl bromide), 133.2 (C-5), 137.6 (benzyl bromide), 138.7 (C-1"), 156.1 (C-2); m/z 202 (M+44, 7\%), 139 (29), 138 (26), 111 (23), 110 (35), 108 (17), 107 (14), 91 (100), 82 (14), 81 (35), 79 (23), 77 (14), 53 (44), 51 (24). 
2-Ethoxy-3-(1'-methoxymethoxyethyl)furan (15). Chloromethyl methyl ether (2.38 g, 29.51 mmol) was added dropwise to a solution of $N, N$-diisopropylethylamine (4.58 g, $19.94 \mathrm{mmol}$ ) and 2-ethoxy-3-(1'-hydroxyethyl)furan 13 (0.46 g, $2.95 \mathrm{mmol})$ in dry dichloromethane (45 $\mathrm{mL})$ at $0{ }^{\circ} \mathrm{C}$. The mixture was stirred at $0{ }^{\circ} \mathrm{C}$ for $10 \mathrm{~min}$ and allowed to warm to room temperature over $3 \mathrm{~h}$. It was then quenched with water and the aqueous layer extracted with dichloromethane. The combined organic layers were dried (magnesium sulfate). Column chromatography (5-10\% ethyl acetate-petroleum ether) of the crude solution gave the title compound 15 (0.42 g, 70\%) (Found: $\mathrm{M}^{+}$, 200.1052. $\mathrm{C}_{10} \mathrm{H}_{16} \mathrm{O}_{4}$ requires $\left.\mathrm{M}, 200.1048\right) ; v_{\max } / \mathrm{cm}^{-1} 2980(\mathrm{C}-\mathrm{H}), 1642(\mathrm{C}=\mathrm{C}) ; \delta_{\mathrm{H}}$ 1.35 (3H, t, $J$ 7.1, $\mathrm{CH}_{2} \mathrm{CH}_{3}$ ), 1.42 (3H, d, $J$ 6.6, 1'- $\mathrm{CH}_{3}$ ), 3.36 (3H, s, $\left.\mathrm{OCH}_{3}\right), 4.19$ (2H, q, $J$ 7.1, $\mathrm{C}_{2} \mathrm{CH}_{3}$ ), 4.52 and 4.60 (each $1 \mathrm{H}, \mathrm{d}, J$ 6.6, $\left.\mathrm{OCH}_{2} \mathrm{O}\right), 4.73(1 \mathrm{H}, \mathrm{q}, J 6.6,1 '-\mathrm{H}), 6.29(1 \mathrm{H}, \mathrm{d}, J$ 2.2, 4-H), $6.88\left(1 \mathrm{H}, \mathrm{d}, J\right.$ 2.2, 5-H); $\delta_{\mathrm{C}} 15.1\left(\mathrm{CH}_{2} \mathrm{CH}_{3}\right), 21.6\left(\mathrm{C}-2^{\prime}\right), 55.2\left(\mathrm{OCH}_{3}\right), 64.6\left(\mathrm{C}-1^{\prime}\right), 68.7$ $\left(\mathrm{CH}_{2} \mathrm{CH}_{3}\right), 93.6\left(\mathrm{OCH}_{2} \mathrm{O}\right), 101.2$ (C-3), 109.9 (C-4), 133.4 (C-5), 156.3 (C-2); m/z $200\left(\mathrm{M}^{+}\right.$, 27\%), 170 (15), 139 (100), 138 (76), 125 (20), 111 (72), 110 (70), 81 (76), 53 (95).

Dimethyl 2-ethoxyfuran-3,4-dicarboxylate (16). A solution of dimethyl acetylenedicarboxylate (0.240 g, $1.69 \mathrm{mmol})$ and 3-acetyl-2-ethoxyfuran 11 (87 mg, $0.56 \mathrm{mmol})$ in dry benzene (10 mL) was heated under reflux for 2 days (47 h). The mixture was cooled and the solvent removed under vacuum. The residue was dissolved in diethyl ether and washed with water. Purification by chromatography (radial, 10-20\% ethyl acetate-petroleum ether) gave known ${ }^{7}$ furan 16 as a yellow oil (52 mg, 40\%) (Found: C, 52.85; H, 5.0. $\mathrm{C}_{10} \mathrm{H}_{12} \mathrm{O}_{6}$ requires $\mathrm{C}, 52.6 ; \mathrm{H}, 5.3 \%$ ); $v_{\max } / \mathrm{cm}^{-}$ $12956(\mathrm{C}-\mathrm{H}), 1727(\mathrm{C}=\mathrm{O}), 1438(\mathrm{C}=\mathrm{C}) ; \delta_{\mathrm{H}} 1.28$ (3H, t, J 7.0, $\mathrm{CH}_{2} \underline{\mathrm{C}}_{3}$ ), 3.80 and 3.887 (each $3 \mathrm{H}, \mathrm{s}, 3-\mathrm{CO}_{2} \mathrm{CH}_{3}$ and 4- $\left.\mathrm{CO}_{2} \mathrm{CH}_{3}\right), 3.886\left(2 \mathrm{H}, \mathrm{q}, J\right.$ 7.0, $\left.\mathrm{CH}_{2} \mathrm{CH}_{3}\right), 5.80(1 \mathrm{H}, \mathrm{s}, 5-\mathrm{H}) ; \delta_{\mathrm{C}} 15.3$

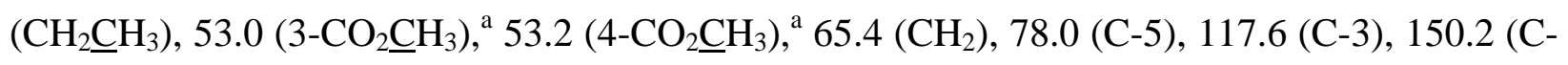
2), $152.0(\mathrm{C}-4),{ }^{\mathrm{b}} 161.4\left(3-\mathrm{CO}_{2}\right),{ }^{\mathrm{c}} 162.9\left(4-\mathrm{CO}_{2}\right){ }^{\mathrm{c}}{ }^{\mathrm{b}} \mathrm{m} / \mathrm{z} 228\left(\mathrm{M}^{+}, 4 \%\right), 200$ (16), 168 (93), 140 (31), 111 (17), 82 (100), 53 (42).

Dimethyl 3-ethoxy-6-hydroxy-4-(1'-hydroxyethyl)benzene-1,2-dicarboxylate (18). Dimethyl acetylenedicarboxylate $(0.224 \mathrm{~g}, 1.58 \mathrm{mmol})$ was added dropwise to a solution of 2-ethoxy-3-(1'hydroxyethyl)furan 13 (82 $\mathrm{mg}, 0.52 \mathrm{mmol})$ in dry benzene $(5 \mathrm{~mL})$. The mixture was stirred at room temperature for $45 \mathrm{~min}$ and then concentrated under vacuum. The crude oil was purified by column chromatography (30\% ethyl acetate-petroleum ether) to give an unstable clear oil, dimethyl 3-ethoxy-4-(1'-hydroxyethyl)-3,6-epoxy-3,6-dihydrobenzene-1,2-dicarboxylate 17 (0.113 g, 72\%); $\delta_{\mathrm{H}}(60 \mathrm{MHz}) 1.13-1.38$ (6H, m, $\mathrm{CH}_{2} \mathrm{CH}_{3}$ and 1'- $\left.\mathrm{CH}_{3}\right), 2.72$ (1H, br. s, OH), 3.56$3.80\left(2 \mathrm{H}, \mathrm{m}, \mathrm{CH}_{2}\right), 3.71$ and 3.80 (each $3 \mathrm{H}, \mathrm{s}, 1-\mathrm{CO}_{2} \mathrm{CH}_{3}$ and $\left.2-\mathrm{CO}_{2} \mathrm{CH}_{3}\right), 4.60(1 \mathrm{H}, \mathrm{q}, \mathrm{J}$ 6.6, 1'$\mathrm{H}), 5.40(1 \mathrm{H}, \mathrm{d}, \mathrm{J} 2.4,6-\mathrm{H}), 6.75(1 \mathrm{H}, \mathrm{d}, \mathrm{J} 2.4,5-\mathrm{H})$. The product was then dissolved in methanol (4 mL) and concentrated hydrochloric acid (4 drops) added. The solution was stirred for $1 \mathrm{~h} 40$ min and then concentrated under vacuum. Water was added to the residue and the mixture was 
extracted with diethyl ether. The combined organic layers were dried (magnesium sulfate), concentrated and chromatographed (10\% ethyl acetate-petroleum ether) to give the title compound 18 as a clear oil (96 mg, 85\%) (Found: C, 56.3; H, 6.1. $\mathrm{C}_{14} \mathrm{H}_{18} \mathrm{O}_{7}$ requires C, 56.35; H, 6.1\%); $v_{\max } / \mathrm{cm}^{-1} 3433(\mathrm{O}-\mathrm{H}), 2977(\mathrm{C}-\mathrm{H}), 1737(\mathrm{C}=\mathrm{O}), 1680(\mathrm{C}=\mathrm{O}), 1439(\mathrm{C}=\mathrm{C}) ; \delta_{\mathrm{H}} 1.34$ (3H, t, J 7.0, $\mathrm{CH}_{2} \mathrm{CH}_{3}$ ), 1.48 (3H, d, J 6.4, 1'- $\mathrm{CH}_{3}$ ), 2.45 (1H, br. s, 1'-OH), 3.908 and 3.910 (each $3 \mathrm{H}, \mathrm{s}, 1-\mathrm{CO}_{2} \mathrm{CH}_{3}$ and 2- $\left.\mathrm{CO}_{2} \mathrm{CH}_{3}\right), 3.85-3.96\left(2 \mathrm{H}, \mathrm{m}, \mathrm{CH}_{2}\right), 5.10(1 \mathrm{H}, \mathrm{q}, \mathrm{J}$ 6.4, 1'-H), $7.17(1 \mathrm{H}, \mathrm{s}$, 5-H), $10.74\left(1 \mathrm{H}, \mathrm{s}, 6^{\prime}-\mathrm{OH}\right) ; \delta_{\mathrm{C}} 15.6\left(\mathrm{CH}_{2} \mathrm{CH}_{3}\right), 23.6\left(\mathrm{C}-2{ }^{\prime}\right), 52.6\left(1-\mathrm{CO}_{2} \underline{\mathrm{CH}}_{3}\right),{ }^{\mathrm{a}} 52.9$ (2$\left.\mathrm{CO}_{2} \underline{\mathrm{CH}}_{3}\right),{ }^{\mathrm{a}} 64.4$ (C-1'), $72.0\left(\mathrm{CH}_{2}\right), 108.1$ (C-4), 116.6 (C-5), 129.5 (C-2), 145.4 (C-3), 148.3 (C-6), $158.4(\mathrm{C}-1), 167.7\left(1-\mathrm{CO}_{2}\right),{ }^{\mathrm{c}} 168.6\left(2-\mathrm{CO}_{2}\right){ }^{\mathrm{c}}{ }^{\mathrm{c}} \mathrm{m} / \mathrm{z} 298\left(\mathrm{M}^{+}, 42 \%\right), 266$ (30), 237 (25), 220 (100), 188 (38), 178 (10), 162 (19), 134 (10), 77 (12), 59 (10).

1-Benzyloxy-1-(4'-acetoxy-6',8'-dimethoxy-1'-ethoxy-2'-naphthalenyl)ethane (24). Butyllithium (1.20 mL, $1.90 \mathrm{M}$ in cyclohexane) was added to a stirred solution of bromotosylate 19 (0.129 g, $0.33 \mathrm{mmol}$ ) and furan 14 (mixture of $82 \mathrm{mg}, 0.33 \mathrm{mmol}$ of compound 14 and $0.268 \mathrm{~g}, 1.57 \mathrm{mmol}$ of benzyl bromide) in dry tetrahydrofuran $(8 \mathrm{~mL})$ at $-78{ }^{\circ} \mathrm{C}$. The reaction was stirred at $-78{ }^{\circ} \mathrm{C}$ for $25 \mathrm{~min}$ then allowed to warm to room temperature over $20 \mathrm{~min}$. Trifluoroacetic acid (10 drops) was added and the mixture stirred for $10 \mathrm{~min}$. The reaction was quenched with saturated aqueous sodium hydrogen carbonate and extracted with diethyl ether. Dry triethylamine (2 mL) was added and the organic solution dried (magnesium sulfate) and then concentrated. The residue was dissolved in dry pyridine $(2 \mathrm{~mL})$ and acetic anhydride $(0.204 \mathrm{~g}, 2.00 \mathrm{mmol})$ was added. The reaction was stirred at room temperature overnight $(14 \mathrm{~h})$, quenched with water and extracted with dichloromethane. The organic extracts were washed with hydrochloric acid (1M) and water. The extracts were then dried (magnesium sulfate), concentrated and chromatographed (radial, $15 \%$ ethyl acetate-petroleum ether) to give two products. The higher $\mathrm{R}_{\mathrm{f}}$ product identified as 1-benzyloxy-1-(6',8'-dimethoxy-1'-ethoxy-4'-hydroxy-2'-naphthalenyl)ethane 23 (10 mg, 8\%) (Found: $\mathrm{M}^{+}$, 382.1763. $\mathrm{C}_{23} \mathrm{H}_{26} \mathrm{O}_{5}$ requires $\left.\mathrm{M}, 382.1780\right) ; v_{\max } / \mathrm{cm}^{-1} 3432(\mathrm{O}-\mathrm{H}), 2971$ $(\mathrm{C}-\mathrm{H}), 1621(\mathrm{C}=\mathrm{C}), 1457(\mathrm{C}=\mathrm{C}) ; \delta_{\mathrm{H}} 1.45\left(3 \mathrm{H}, \mathrm{t}, J\right.$ 7.0, $\left.\mathrm{CH}_{2} \underline{\mathrm{CH}}_{3}\right), 1.52$ (3H, d, J 6.4, 1- $\left.\mathrm{CH}_{3}\right)$, 3.85-3.91 (2H, m, $\mathrm{CH}_{2} \mathrm{CH}_{3}$ ), 3.92 and 4.03 (each $3 \mathrm{H}, \mathrm{s}, 6^{\prime}-\mathrm{OCH}_{3}$ and 8'-OCH$_{3}$ ), 4.32 and 4.42 (each 1H, d, J 11.7, $\left.\mathrm{CH}_{2} \mathrm{Ph}\right), 5.06$ (1H, q, J 6.4, 1-H), 6.49 (1H, d, J 2.2, 7'-H), 6.88 (1H, s, 3'-H), 6.97 (1H, d, J 2.2, 5'-H), 7.32-7.34 (5H, m, Ph-H); $\delta_{\mathrm{C}} 15.9\left(\mathrm{CH}_{2} \underline{\left.\mathrm{CH}_{3}\right),} 23.3\right.$ (C-2), 55.3 (6'$\left.\mathrm{OCH}_{3}\right),{ }^{\mathrm{a}} 56.2\left(8^{\prime}-\mathrm{OCH}_{3}\right),{ }^{\mathrm{a}} 70.1\left(\underline{\mathrm{CH}}_{2} \mathrm{Ph}\right),{ }^{\mathrm{b}} 70.4\left(\underline{\mathrm{CH}}_{2} \mathrm{CH}_{3}\right),{ }^{\mathrm{b}} 70.8(\mathrm{C}-1), 94.1\left(\mathrm{C}-5^{\prime}\right), 97.8\left(\mathrm{C}-7^{\prime}\right)$, 105.4 (C-3'), 111.0 (C-8a'), 127.4 (C-4"), 127.8 (C-2" and C-6"), ${ }^{c} 128.3$ (C-3" and C-5"), ${ }^{\mathrm{c}} 131.3$ (C-2'), ${ }^{\mathrm{d}} 134.6$ (C-4a'), ${ }^{\mathrm{d}} 138.7$ (C-1"), 144.1 (C-1'), 151.3 (C-4'), ${ }^{\mathrm{e}} 157.6$ (C-6'), ${ }^{\mathrm{f}} 158.1\left(\mathrm{C}-8^{\prime}\right) ;{ }^{\mathrm{f}} \mathrm{m} / \mathrm{z}$ 382 (M+, 65\%), 274 (47), 247 (84), 246 (33), 245 (100), 220 (23), 149 (20), 108 (89). The lower $\mathrm{R}_{\mathrm{f}}$ product was identified as the title compound 24 (34 mg, 24\%) (Found: C, 70.1; H, 6.55; $\mathrm{M}^{+}$, 424.1865. $\mathrm{C}_{25} \mathrm{H}_{28} \mathrm{O}_{5}$ requires C, 70.75; H, 6.65\%; M, 424.1886); $v_{\max } / \mathrm{cm}^{-1} 2975$ (C-H), 1767 $(\mathrm{C}=\mathrm{O}), 1627(\mathrm{C}=\mathrm{C}), 1612(\mathrm{C}=\mathrm{C}) ; \delta_{\mathrm{H}} 1.42\left(3 \mathrm{H}, \mathrm{t}, J\right.$ 7.0, $\left.\mathrm{CH}_{2} \underline{\mathrm{CH}}_{3}\right), 1.52\left(3 \mathrm{H}, \mathrm{d}, J\right.$ 6.4, 1- $\left.\mathrm{CH}_{3}\right)$, 
2.44 (3H, s, $\left.\mathrm{COCH}_{3}\right)$, 3.82-3.93 (2H, m, $\left.\mathrm{CH}_{2} \mathrm{CH}_{3}\right)$, 3.89 and 3.96 (each 3H, s, 6'-OCH ${ }_{3}$ and 8'$\mathrm{OCH}_{3}$ ), 4.34 and 4.40 (each $1 \mathrm{H}, \mathrm{d}, J$ 11.5, $\mathrm{CH}_{2} \mathrm{Ph}$ ), 5.15 (1H, q, $J$ 6.4, 1-H), 6.56 and 6.68 (each $1 \mathrm{H}, \mathrm{d}, J$ 2.3, 5'-H and 7'-H), 7.31-7.33 (5H, m, Ph-H), 7.37 (1H, s, 3'-H); $\delta_{\mathrm{C}} 15.4\left(\mathrm{CH}_{2} \mathrm{CH}_{3}\right)$, $21.0\left(\mathrm{COCH}_{3}\right), 23.7(\mathrm{C}-2), 55.1\left(6^{\prime}-\mathrm{OCH}_{3}\right),{ }^{\mathrm{a}} 56.0\left(8^{\prime}-\mathrm{OCH}_{3}\right),{ }^{\text {a }} 70.5\left(\mathrm{CH}_{2} \mathrm{Ph}\right), 70.7(\mathrm{C}-1), 71.3$ ( $\mathrm{CH}_{2} \mathrm{CH}_{3}$ ), 92.3 (C-5'), 99.4 (C-7'), 116.7 (C-8a'), 117.7 (C-3'), 127.3 (C-4"), 127.8 (C-2" and C6"), 128.2 (C-3" and C-5"), 130.3 (C-2'), 130.6 (C-4a'), ${ }^{\mathrm{c}} 138.6$ (C-1"), 142.3 (C-1'), 150.5 (C4'), 157.5 (C-6'), 158.5 (C-8'), 169.4 (CO); m/z 423 (M+1, 10\%), 316 (68), 274 (78), 259 (40), 245 (100), 217 (37), 214 (11), 159 (10), 128 (12), 115 (21), 108 (28), 107 (24), 91 (34), 77 (63), 69 (11), 63 (17), 51 (26).

\section{1-(4'-Acetoxy-6',8'-dimethoxy-1'-ethoxy-2'-naphthalenyl)-1-(methoxymethoxy)-ethane (26).}

Butyllithium (0.48 mL, 2.29 $\mathrm{M}$ in hexane) was added to a solution of bromotosylate 19 (0.387 g, $1.00 \mathrm{mmol})$, furan 15 (0.200 g, $1.00 \mathrm{mmol})$ and $4 \AA$ molecular sieves (1 g) in dry tetrahydrofuran $(8 \mathrm{~mL})$ at $-78{ }^{\circ} \mathrm{C}$. The mixture was stirred at this temperature for $15 \mathrm{~min}$ then allowed to warm to room temperature over 20 min. Trifluoroacetic acid (20 drops) was added and the reaction mixture stirred for $1 \mathrm{~h}$. The reaction was quenched with water, extracted with diethyl ether and the extracts washed with saturated aqueous sodium hydrogen carbonate and saturated aqueous sodium chloride. The extracts were then dried (magnesium sulfate) and concentrated. The residue was dissolved in dry pyridine $(4 \mathrm{~mL})$ and acetic anhydride $(0.612 \mathrm{~g}, 5.99 \mathrm{mmol})$ was added. The reaction was stirred overnight (22 h), quenched with water and extracted with dichloromethane. The extracts were washed with hydrochloric acid (1M) and water and then dried (magnesium sulfate). The crude solution was chromatographed (10-20\% ethyl acetatepetroleum ether) to give the oily title compound 26 (0.155 g, 41\%) (Found: C, 63.4; H, 7.0. $\mathrm{C}_{20} \mathrm{H}_{26} \mathrm{O}_{7}$ requires C, 63.5; $\left.\mathrm{H}, 6.95 \%\right) ; v_{\max } / \mathrm{cm}^{-1} 2974(\mathrm{C}-\mathrm{H}), 1766(\mathrm{C}=\mathrm{O}), 1612(\mathrm{C}=\mathrm{C}) ; \delta_{\mathrm{H}} 1.48$ $\left(3 \mathrm{H}, \mathrm{t}, J\right.$ 7.0, $\left.\mathrm{CH}_{2} \mathrm{CH}_{3}\right), 1.49\left(3 \mathrm{H}, \mathrm{d}, J\right.$ 6.5, 1- $\left.\mathrm{CH}_{3}\right), 2.43\left(3 \mathrm{H}, \mathrm{s}, \mathrm{COCH}_{3}\right), 3.37(3 \mathrm{H}, \mathrm{s}$, $\mathrm{CH}_{2} \mathrm{OCH}_{3}$ ), 3.89 and 3.96 (each $3 \mathrm{H}, \mathrm{s}, 6^{\prime}-\mathrm{OCH}_{3}$ and 8'- $-\mathrm{OCH}_{3}$ ), 3.92 and 3.93 (each 1H, q, $J$ 7.0, $\mathrm{CH}_{2} \mathrm{CH}_{3}$ ), 4.57 and 4.58 (each $1 \mathrm{H}, \mathrm{d}, J$ 6.5, $\mathrm{OCH}_{2} \mathrm{O}$ ), $5.33(1 \mathrm{H}, \mathrm{q}, J$ 6.5, 1-H), 6.54 and 6.65 (each 1H, d, $J$ 2.3, 5'-H and 7'-H), $7.28\left(1 \mathrm{H}, \mathrm{s}, 3^{\prime}-\mathrm{H}\right)$; $\delta_{\mathrm{C}} 15.6\left(\mathrm{CH}_{2} \underline{\mathrm{CH}} 3\right), 21.0\left(\mathrm{COCH}_{3}\right), 23.5(\mathrm{C}-$ 2), $55.2\left(\mathrm{CH}_{2} \mathrm{OCH}_{3}\right),{ }^{\mathrm{a}} 55.4\left(6^{\prime}-\mathrm{OCH}_{3}\right),{ }^{\mathrm{a}} 56.1\left(8^{\prime}-\mathrm{OCH}_{3}\right),{ }^{\mathrm{a}} 67.7(\mathrm{C}-1), 71.3\left(\underline{\mathrm{CH}}_{2} \mathrm{CH}_{3}\right), 92.3\left(\mathrm{C}-5^{\prime}\right)$, $94.3\left(\mathrm{OCH}_{2} \mathrm{O}\right), 99.4$ (C-7'), 116.8 (C-8a'), 117.8 (C-3'), 130.2 (C-2'), $130.5\left(\mathrm{C}-4 \mathrm{a}^{\prime}\right),{ }^{\mathrm{b}} 142.2(\mathrm{C}-$ $\left.1^{\prime}\right),{ }^{\mathrm{c}} 150.2\left(\mathrm{C}-4^{\prime}\right),{ }^{\mathrm{c}} 157.6\left(\mathrm{C}-6^{\prime}\right),{ }^{\mathrm{d}} 158.5$ (C-8'), ${ }^{\mathrm{d}} 169.4(\mathrm{CO}) ; \mathrm{m} / \mathrm{z} 379\left(\mathrm{M}^{+}+1,10 \%\right), 378\left(\mathrm{M}^{+}, 31\right)$, 336 (28), 316 (53), 275 (40), 274 (32), 259 (24), 245 (34), 231 (24), 217 (14), 214 (11), 131 (16), 119 (10), 115 (10), 93 (12), 77 (10), 73 (20), 69 (100). 


\section{1-(6',8'-Dimethoxy-1'-ethoxy-4'-isopropoxy-2'-naphthalenyl)-1-(methoxymethoxy) ethane (27).} Butyllithium (0.33 mL, $1.67 \mathrm{M}$ in hexane) was added to a solution of bromotosylate 19 (0.193 g, $0.50 \mathrm{mmol})$, furan 15 (0.100 g, $0.50 \mathrm{mmol})$ and $4 \AA$ molecular sieves ( $1 \mathrm{~g})$, in dry tetrahydrofuran $(4 \mathrm{~mL})$ at $-78{ }^{\circ} \mathrm{C}$. The reaction was stirred for $25 \mathrm{~min}$ at $-78{ }^{\circ} \mathrm{C}$ and then allowed to warm to room temperature over 25 min. Trifluoroacetic acid (20 drops) was added and the mixture stirred for $1 \mathrm{~h}$. The reaction mixture was quenched with water, extracted with diethyl ether, and the extracts washed with saturated aqueous sodium hydrogen carbonate and saturated aqueous sodium chloride. The extracts were dried (magnesium sulfate) and concentrated. The residue was dissolved in dry dimethylformamide $(8 \mathrm{~mL})$ and 2-bromopropane $(0.246 \mathrm{~g}, 2.00 \mathrm{mmol})$ was added. Potassium carbonate $(0.276 \mathrm{~g}, 2.00 \mathrm{mmol})$ was added to the reaction mixture, which was then stirred under reflux overnight $(17 \mathrm{~h})$. The reaction was then quenched with water, extracted with diethyl ether and the extracts washed with water. The extracts were dried (magnesium sulfate) and concentrated. The residue was then chromatographed (radial, 10-20\% ethyl acetatepetroleum ether) to give two products. The higher $\mathrm{R}_{\mathrm{f}}$ product was identified as the oily title compound 27 (18 mg, 10\%) (Found: $\mathrm{M}^{+}$, 378.2047. $\mathrm{C}_{21} \mathrm{H}_{30} \mathrm{O}_{6}$ requires $\mathrm{M}, 378.2042$ ); $v_{\max } / \mathrm{cm}^{-1}$ $2975(\mathrm{C}-\mathrm{H}), 1605(\mathrm{C}=\mathrm{C}) ; \delta_{\mathrm{H}} 1.42\left(6 \mathrm{H}, \mathrm{d}, J\right.$ 6.0, $\left.\mathrm{CH}\left(\mathrm{CH}_{3}\right)_{2}\right), 1.46$ (3H, t, J 6.6, $\left.\mathrm{CH}_{2} \mathrm{C}_{3}\right), 1.49$ $\left(3 \mathrm{H}, \mathrm{d}, J\right.$ 6.5, 1- $\left.\mathrm{CH}_{3}\right), 3.39\left(3 \mathrm{H}, \mathrm{s}, \mathrm{OCH}_{2} \mathrm{OCH}_{3}\right), 3.79-3.90\left(2 \mathrm{H}, \mathrm{m}, \mathrm{CH}_{2} \mathrm{CH}_{3}\right), 3.92$ and 3.95 (each $3 \mathrm{H}, \mathrm{s}, 6^{\prime}-\mathrm{OCH}_{3}$ and 8'- $\mathrm{OCH}_{3}$ ), 4.55 and 4.58 (each $1 \mathrm{H}, \mathrm{d}, J$ 6.5, $\left.\mathrm{OCH}_{2} \mathrm{O}\right), 4.69(1 \mathrm{H}$, septet, $J$ 6.0, $\left.\mathrm{C} \underline{\mathrm{H}}\left(\mathrm{CH}_{3}\right)_{2}\right), 5.36$ (1H, q, J 6.5, 1-H), 6.55 (1H, d, J 2.3, 7'-H), 6.92 (1H, s, 3'-H), 7.19 (1H, d, J 2.3, 5'-H); $\delta_{\mathrm{C}} 13.7\left(\mathrm{CH}_{2} \underline{\mathrm{CH}}_{3}\right), 20.3\left(\mathrm{CH}\left(\underline{\mathrm{CH}}_{3}\right)_{2}\right), 21.7(\mathrm{C}-2), 53.3\left(\mathrm{CH}_{2} \mathrm{OCH}_{3}\right)$, ${ }^{\mathrm{a}} 53.4\left(6^{\prime}-\right.$ $\left.\mathrm{OCH}_{3}\right),{ }^{\mathrm{a}} 54.1\left(8^{\prime}-\mathrm{OCH}_{3}\right),{ }^{\mathrm{a}} 65.9(\mathrm{C}-1),{ }^{\mathrm{b}} 68.8\left(\underline{\mathrm{CH}}\left(\mathrm{CH}_{3}\right)_{2}\right),{ }^{\mathrm{b}} 69.1\left(\mathrm{CH}_{2} \mathrm{CH}_{3}\right), 91.6(\mathrm{C}-5$ '), 92.2 $\left(\mathrm{OCH}_{2} \mathrm{O}\right), 97.4\left(\mathrm{C}-7^{\prime}\right), 104.2$ (C-3'), 114.5 (C-8a'), $127.9\left(\mathrm{C}-2^{\prime}\right){ }^{\mathrm{c}} 128.0\left(\mathrm{C}-4 \mathrm{a}^{\prime}\right),{ }^{\mathrm{c}} 143.8\left(\mathrm{C}-1^{\prime}\right),{ }^{\mathrm{d}}$ 147.2 (C-4'), ${ }^{\mathrm{d}} 155.3$ (C-6'), 155.7 (C-8'); ${ }^{\mathrm{e}} \mathrm{m} / \mathrm{z} 378$ (M+1, 15\%), 317 (22), 316 (93), 274 (12), 246 (18), 245 (100), 231 (15), 217 (46), 215 (13), 202 (14), 201 (12), 171 (12), 159 (15), 145 (11), 143 (12), 128 (12), 115 (10), 77 (10), 69 (12). The lower $\mathrm{R}_{\mathrm{f}}$ product was identified as the unstable 1-(6',8'-dimethoxy-1'-ethoxy-4'-hydroxy-2'-naphthalenyl)-1-(methoxymethoxy)ethane 25 (39 mg, 23\%) as pale yellow needles mp 69.5-71 ${ }^{\circ} \mathrm{C}$ (from diethyl ether-hexane); $v_{\max } / \mathrm{cm}^{-1}$ $3019(\mathrm{O}-\mathrm{H}), 1610(\mathrm{C}=\mathrm{C}) ; \delta_{\mathrm{H}} 1.47$ (3H, t, $J$ 7.0, $\left.\mathrm{CH}_{2} \mathrm{CH}_{3}\right), 1.51$ (3H, d, $J$ 6.5, 1- $\left.\mathrm{CH}_{3}\right), 3.41$ (3H, s, $\mathrm{CH}_{2} \mathrm{OC}_{3}$ ), 3.86-3.94 (2H, m, $\underline{\mathrm{CH}}_{2} \mathrm{CH}_{3}$ ), 3.92 and 3.96 (each $3 \mathrm{H}, \mathrm{s}, 6{ }^{\prime}-\mathrm{OCH}_{3}$ and 8'- $\mathrm{OCH}_{3}$ ), 4.55 and 4.62 (each 1H, d, $J$ 6.6, $\left.\mathrm{OCH}_{2} \mathrm{O}\right), 5.41(1 \mathrm{H}, \mathrm{q}, J$ 6.5, 1-H), $6.56(1 \mathrm{H}, \mathrm{d}, J$ 1.2, 7'-H), 7.02 (1H, s, 3'-H), 7.12 (1H, d, J 1.2, 5'-H); $\delta_{\mathrm{C}} 15.6\left(\mathrm{CH}_{2} \underline{\mathrm{C}}_{3}\right), 23.5(\mathrm{C}-2), 55.4\left(\mathrm{CH}_{2} \mathrm{OCH}_{3}\right),{ }^{\mathrm{a}} 55.6$ $\left(6^{\prime}-\mathrm{OCH}_{3}\right),{ }^{\mathrm{a}} 56.0\left(8^{\prime}-\mathrm{OCH}_{3}\right),{ }^{\mathrm{a}} 68.0(\mathrm{C}-1), 71.2\left(\mathrm{CH}_{2} \mathrm{CH}_{3}\right), 93.2(\mathrm{C}-5 '), 94.0\left(\mathrm{OCH}_{2} \mathrm{O}\right), 99.6\left(\mathrm{C}-7{ }^{\prime}\right)$, 107.1 (C-3'), 116.5 (C-8a'), 127.9 (C-2'), 129.6 (C-4a'), ${ }^{\text {b }} 146.0$ (C-1'), ${ }^{c} 147.7$ (C-4'), 157.3 (C6'), 157.7 (C-8'); ${ }^{\mathrm{d}} \mathrm{m} / \mathrm{z} 335$ (M+1, 36\%), 306 (26), 274 (19), 262 (34), 261 (94), 260 (100), 245 (24), 244 (21), 217 (22), 215 (24), 115 (32), 106 (26), 91 (21), 69 (21), 63 (29), 62 (21), 51 (21), 50 (32). 
6,8-Dimethoxy-1-ethoxy-4-isopropoxy-2-vinylnaphthalene (28). (a) Pyridinium p-toluenesulfonate (0.159 g, $0.63 \mathrm{mmol}$ ) was added to a solution of naphthalene 27 (35 mg, $0.09 \mathrm{mmol}$ ) in 2butanone $(10 \mathrm{~mL})$. The reaction was immediately heated under reflux for $30 \mathrm{~min}$, cooled and concentrated. The residue was chromatographed (radial, 20\% ethyl acetate-petroleum ether) to give the oily product 28 (16 mg, 55\%) (Found: $\mathrm{M}^{+}$, 316.1665. $\mathrm{C}_{19} \mathrm{H}_{24} \mathrm{O}_{4}$ requires $\mathrm{M}, 316.1675$ ); $v_{\max } / \mathrm{cm}^{-1} 2928(\mathrm{C}-\mathrm{H}), 1619(\mathrm{C}=\mathrm{C}), 1603(\mathrm{C}=\mathrm{C}), 1577(\mathrm{C}=\mathrm{C}) ; \delta_{\mathrm{H}} 1.446(6 \mathrm{H}, \mathrm{d}, J$ 6.0, $\mathrm{CH}\left(\mathrm{CH}_{3}\right)_{2}$ ), 1.447 (3H, t, $J$ 6.9, $\mathrm{CH}_{2} \underline{\mathrm{CH}}_{3}$ ), 3.85 (2H, q, $J$ 6.9, $\mathrm{C}_{2} \mathrm{CH}_{3}$ ), 3.92 and 3.95 (each 3H, s, 6- $-\mathrm{OCH}_{3}$ and 8- $\left.\mathrm{OCH}_{3}\right)$, 4.66-4.74 (1H, septet, $J$ 6.0, $\left.\mathrm{C} \underline{\mathrm{H}}\left(\mathrm{CH}_{3}\right)_{2}\right), 5.26(1 \mathrm{H}$, dd, $J 1.1$ and 11.1, vinyl $\mathrm{CH}_{2}$ ), 5.68 (1H, dd, $J 1.1$ and 17.8, vinyl $\left.\mathrm{CH}_{2}\right), 6.54(1 \mathrm{H}, \mathrm{d}, J$ 2.4, 7-H), $7.02(1 \mathrm{H}, \mathrm{s}, 3-\mathrm{H})$, $7.17\left(1 \mathrm{H}, \mathrm{d}, J\right.$ 2.4, 5-H), $7.27(1 \mathrm{H}$, dd, $J 11.1$ and 17.8, vinyl $\mathrm{CH}) ; \delta_{\mathrm{C}} 15.4\left(\mathrm{CH}_{2} \mathrm{CH}_{3}\right), 22.3$ $\left(\mathrm{CH}\left(\underline{\mathrm{CH}}_{3}\right)_{2}\right), 55.2\left(6-\mathrm{OCH}_{3}\right),{ }^{\mathrm{a}} 56.1\left(8-\mathrm{OCH}_{3}\right),{ }^{\mathrm{a}} 70.97\left(\underline{\mathrm{CH}}\left(\mathrm{CH}_{3}\right)_{2}\right), 71.03\left(\underline{\mathrm{CH}}_{2} \mathrm{CH}_{3}\right), 93.8(\mathrm{C}-5)$, 99.4 (C-7), 105.1 (C-3), $112.5\left(\mathrm{CHCH}_{2}\right), 116.81$ (C-8a), 124.7 (C-2), ${ }^{\mathrm{b}} 130.7$ (C-4a), 132.0

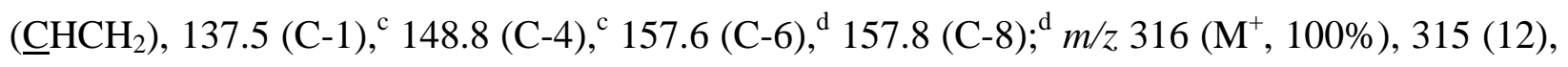
287 (11), 274 (18), 273 (32), 246 (14), 245 (95), 231 (12), 217 (40), 202 (11), 187 (13), 174 (11), 159 (11).

(b) Trimethylsilyl bromide $(0.184 \mathrm{~g}, 1.20 \mathrm{mmol})$ was added to a solution of compound $27(0.114$ g, $0.30 \mathrm{mmol})$ and $4 \AA$ molecular sieves $(0.5 \mathrm{~g})$ in dry dichloromethane $(10 \mathrm{~mL})$ at $-78{ }^{\circ} \mathrm{C}$. The reaction was stirred at $-78{ }^{\circ} \mathrm{C}$ for $25 \mathrm{~min}$, quenched with saturated aqueous sodium hydrogen carbonate and extracted with dichloromethane. The extracts were dried (magnesium sulfate) and concentrated. The residue was chromatographed (radial, 10\% ethyl acetate-petroleum ether) to give the title compound 28 (14 mg, 14\%). 


\section{Acknowledgements}

Financial support from the Senate of Murdoch University and an Australian Postgraduate Award (to C.P.T) are gratefully acknowledged.

\section{References}

1. (a) Thomson, R. H. In Naturally Occurring Quinones, 2nd Edn., Academic Press: London, 1971. (b) Thomson, R. H. In Naturally Occurring Quinones III, Recent Advances, $3^{\text {rd }}$ Edn., Chapman and Hall: London, 1987. (c) Thomson, R. H. In Naturally Occurring Quinones IV, Recent Advances, $4^{\text {th }}$ Edition, Chapman and Hall: London, 1997.

2. Elsworth, J.F.; Giles, R.G.F.; Green, I.R.; Ramdohr, J.E.; Yorke, S.C. J. Chem. Soc., Perkin Trans. 1 1988, 2469.

3. Naruta, Y.; Uno, H.; Maruyama, K. J. Chem. Soc., Chem. Commun. 1981, 1277.

4. Kobayashi, K.; Uchida, M.; Uneda, T.; Tanmatsu, M.; Morikawa, O.; Konishi, H. Tetrahedron Lett. 1998, 39, 7725.

5. Giles, R.G.F.; Hughes, A.B.; Sargent, M.V. J. Chem. Soc., Perkin Trans. 1 1991, 1581.

6. Yadav, J.S.; Valluri, M.; Rama Rao, A. V. Tetrahedron Lett. 1994, 35, 3609.

7. Grigg, R.; Jackson, J.L. J. Chem. Soc. (C) 1970, 552.

8. Details are provided for our improved synthesis.

9. Zaoral, M.; Kolc, J.; Korenczki, F.; Cherneckii, V.P.; Sorm, F. Collect. Czech. Chem. Commun. 1967, 32, 843.

10. Harris, E.E.; Firestone, R.A.; Pfister, K.; Boettcher, R.R.; Cross, F.J.; Currie, R.B.; Monaco, M.; Peterson, E.R.; Reuter, W. J. Org. Chem. 1962, 27, 2705.

11. (a) Naito, T.; Morita, Y.; Onishi, S.; Tabara, I. Chem. Abstr. 1971, 74, 42347b. (b) Bringmann, G.; Schneider, S. Tetrahedron Lett. 1986, 27, 175.

12. (a) Leane, J.B.; Richards, R.E. Trans. Faraday Soc. 1959, 55, 518. (b) Gronowitz, S.; Sorlin, G.; Gestblom, B. Hoffman, R.A. Arkiv Kemi 1962, 19, 483; Chem. Abstr. 1963, 58, $2041 \mathrm{f}$.

13. (a) Brimble, M.A.; Gibson, J.J; Baker, R.; Brimble, M.T.; Kee, A.A.; O’Mahoney, M.J. Tetrahedron Lett. 1987, 28, 4891. (b) Brimble, M.A.; Phythian, S.J.; Prabaharan, H. J. Chem. Soc., Perkin Trans. 1 1995, 2855 and references cited therein.

14. Friedman, L.; Logullo, F.M. J. Am. Chem. Soc. 1963, 85, 1549.

15. (a) Hoffmann, R.W. In Dehydrobenzene and Cycloalkynes, Academic: New York, 1967, pp 135. (b) Razzuk, A.; Biehl, E.R.; J. Org. Chem. 1987, 52, 2619. 
16. Hanessian, S.; Delorme, D.; Dufresne, Y. Tetrahedron Lett. 1984, 25, 2515.

17. Monti, H.; Leandri, G.; Klos-Ringuet, M.; Corriol, C. Synth. Commun. 1983, 13, 1021. 